\title{
1. The 'superficial' Europeanization of southern Europe: the persistence of peripheral governance
}

\section{INTRODUCTION}

The financial and sovereign debt crisis in the European Union had a devastating impact on southern Europe, not only economically and politically but also socially and culturally. The southern European countries had grown accustomed to a benevolent European Union (EU) that would transfer funding from the EU cohesion policy for the development of the region, no questions asked. This led to a desire on the part of elites and the local populations to perpetuate this relationship without making sufficient efforts to transform their political, economic, and social structures. The period between 2008 and 2014 did not represent a break with the past; rather, the impact of the financial and sovereign debt crisis is simply a confirmation of the ailing semi-peripheral socio-economic model of southern Europe.

The 'Troika' regime was the worst thing that could have happened to the European Union in general and to southern Europe in particular. The EU's image as a community of states acting in solidarity faded away due to policies on the part of the technocratic elites that rule the Economic and Monetary Union (EMU). Specifically, the inclusion of the International Monetary Fund (IMF) in the Troika was a big mistake. Michael Lewis, in his book Boomerang: Travels in the New Third World (2012), presents a damaging assessment of exactly what happened in the EU in the 2010s. The IMF is seldom used to resolve problems in economically more developed economies, and consequently many IMF members from the Global South were not very happy about these interventions. This discontent was reinforced by the extraordinary powers without accountability granted to the intergovernmental Eurogroup, which divided Europe into 'creditor' and 'debtor' states (Laffan, 2016). Nationalist prejudices and stereotypes gained traction in the Eurogroup but also across Europe, particularly in the media.

In this book, we reflect on the impact of the increasingly constraining European political economy on southern European democratic but peripheral 
governance. For a long time, the southern European countries were able to develop their socio-economic policies in an unconstrained fashion, without taking into account sound macro-economic policies. At first, European integration did not alter this situation; however, the Treaty of the European Union (TEU) introduced EMU, which changed the nature of the European Union in this respect. The European Union can be compared to a minor league of European integration, but EMU is a major league which shares responsibility for the global success of the Euro. The introduction of the Euro transformed the European Union into a world economic power overnight, capable of challenging the supremacy of the US dollar. The Euro is now the second-largest currency: in June 2018, over 20 percent of central bank reserves globally were in Euros, and 35.7 percent of global payments used the currency (ECB, 2018: 5). This achievement is remarkable considering the fact that the Eurozone is not an optimal currency area and economic policy is at best a transgovernmental network, not yet supranationalized. Despite the financial and sovereign debt crisis, the Euro has remained a success story. EMU also symbolizes a turning point in the history of European integration, as it has meant the loss of national control over currency for the member-states that join. A core group of 19 member-states of the European Union have effectively pooled their monetary sovereignty in order to compete more efficiently in the global market. In this regard, national narratives on the financial and sovereign debt crisis cannot comprehensively capture what happened to the southern European countries. Once in the Euro, national socio-economic policies are necessarily limited, forcing governments to be macro-economically disciplined. The nations have become part of a larger whole, and national populations must be educated and socialized in this direction. Member-states of EMU, having voluntarily joined the club, operate within a regime of shared sovereignty, and therefore they share responsibility in protecting the Euro. This interpretation of solidarity was not often emphasized during the sovereign debt crisis; in fact, a mentality of methodological nationalism prevailed over methodological Europeanism (see Callaghan, 2010; Magone et al., 2016; Wimmer and Glick Schiller, 2002).

The southern European countries are still stuck in the mode of methodological nationalism; however, the European Union and Economic and Monetary Union are steadily restructuring national economic spaces into a European space. This 'methodological Europeanism' is felt more strongly in the periphery of the EU than in the core countries, due to the problems of peripheral governance. The emergence of populism and resurgent Euroscepticism are just some of the many phenomena that have arisen in response to this change. A type of cleavage between closed-minded nationalists and open-minded Europeanists has developed since the Treaty of the European Union, which came into force in 1993 (Hooghe and Marks, 2018). 
Furthermore, due to the lack of progress in restructuring national economies (methodological nationalism) towards the larger European space (methodological Europeanism), national autonomy in terms of democracy and governance is being constrained quite considerably. We argue that the southern European countries are not well integrated in the EU multilevel governance system; their Europeanization has thus far been superficial. We introduce here the concept of '(semi-)peripheral governance' as a reason for this lack of readjustment to the European dimension.

This book further argues that without a robust political economy, it is difficult for a country to have a high-quality democracy. One of the main reasons is that the dominant form of democracy is capitalist, and the construction of national societies is based on an increasingly globalized capitalist political economy. Notably, countries in the periphery and semi-periphery are losing steering capacity due to the competitive nature of capitalism. Philippe Cerny calls this the 'competition state' - it was always there, but it has become even more prominent since the 1980s. The 'competition state' must adjust its structures efficiently so that it can support its economic basis in a highly competitive globalized economy. This primarily means cutting costs and using its resources related to welfare for the creation of a competitive workforce (Cerny, 1990: 220-229). The contemporary world order has become more competitive, such that individual European states are no longer able to be successful on their own. The BRICS countries (Brazil, Russia, India, China, and South Africa) have become tenacious global players over recent decades, and the centre of capitalism is shifting to Asia (Khanna, 2019). The member-states of the European Community/European Union (EC/EU) have had to pool their resources in order to remain competitive. Over 70 years of European integration a great deal has been accomplished, but mentalities are still far too nationally oriented.

In the following pages, we will first define what we mean by southern Europe. The next section discusses the concept of semi-peripheral economy, politics, society, and culture. This is followed by a definition of Europeanization and how it plays out in a divided political economy of core and (semi-)peripheral countries. Subsequently, the relationship between the European Union and the southern European countries is discussed, which we define as the 'external constraint' (vincolo esterno). Finally, we introduce a heuristic typology of what constitutes semi-peripheral democratic governance, and certain conclusions are drawn. 


\section{THE MAKING OF THE SOUTHERN EUROPEAN SEMI-PERIPHERY}

Although the European Union is accelerating its integration efforts, there are still considerable differences between the various subregions of the continent. Elsewhere, we have differentiated between clusters of countries such as the Nordic countries, Benelux, Germanic-speaking Europe (Germany, Austria, and Switzerland), France, the British Isles, east-central Europe (Poland, Hungary, Czech Republic, Slovakia, and Slovenia), Eastern Europe (Bulgaria, Romania, and Croatia), the Baltic states, the Mediterranean islands (Malta and Cyprus), and southern Europe. Turkey, Ukraine, Russia, Belarus, Moldova, and Georgia are also included as part of a complete Europe (Magone, 2019a: 5-9). The regional cluster of southern Europe consists of four countries: Portugal, Spain, Italy, and Greece. One reason for grouping these nations together is that they show many similarities in terms of historical legacy, integration in the world economy, geopolitical context, and cultural affinity. There will be a thorough discussion of these comparisons throughout the book; for now, it suffices to delineate these features briefly (Magone, 2016c; 2019a; in more detail, Magone, 2003; see also Featherstone and Kazamias, 2001; Gibson, 2001; Hopkin, 2015; Malefakis, 1995; Molina and Rhodes, 2007a; Pridham, 2000; Rhodes, M., 2016; Sapelli, 1995).

\section{The Historical Legacy of Southern Europe: A Discontinuous Process Towards Democracy}

Historically, southern Europe is characterized by a discontinuous process moving towards democracy. Since the seventeenth and eighteenth centuries, Portugal and Spain have had to cope with the decline of empires dominated by rent-seeking elites. The Dutch, French, and British were powerful adversaries that contributed to this decline. Notably, the expansion of the British Empire put an end to the hegemony of the Iberian countries.

The history of democracy in Portugal and Spain starts in the early nineteenth century, when new liberal elites sought to reduce the power of the monarchy by designing new constitutions. The Constitution of Cadiz in 1812 and the Constitution of 1822 in Portugal are examples of this early attempt to introduce liberal regimes. However, none of these constitutions lasted for long, and the nineteenth century was instead dominated by a continuing fight between liberals and conservatives. In Spain, if we ignore the imposed Napoleonic Constitution of 1808, there were eight constitutions between 1812 and 1931, the year in which the monarchy was replaced by the Second Republic (1931-1936). The deteriorating situation of the constitutional mon- 
archy led to the military coup d'état headed by General Miguel de Rivera and the imposition of an authoritarian dictatorship. In 1931, the Second Republic was proclaimed; however, high levels of political and economic instability and political violence between the left and right brought about a bloody civil war and a military dictatorship under General Francisco Franco that lasted until his death on 20 November 1975.

Similarly, in Portugal, there were three constitutions between 1822 and 1910 , the year in which the Republic was proclaimed. However, the primary constitution was that of 1826 , which represented a compromise between liberalism and absolutism. As in Spain, the incipient democracy suffered many interruptions due to coups d'état throughout the nineteenth century. In the twentieth century, long periods of dictatorship further undermined democratization in Portugal and Spain. In Portugal, the failure of the First Republic (1910-1926) led to the rise of the authoritarian regime of (former economics professor) Antonio Oliveira Salazar (1926-1968) and later to that of Marcelo Caetano (1968-1974).

Compared to the Iberian countries, Greece and Italy had a relatively late development in terms of nation- and state-building in the nineteenth century. Greece was under the rule of the Ottoman Empire until 1828. During its war of independence (1821-1830), three constitutions were adopted, only to be suspended again. Notably, various Greek leaders fought against each other as well as against the Ottomans. Some stability was achieved when Otto von Wittelsbach, the second son of King Ludwig I of Bavaria, was installed on the throne (1832-1862). However, throughout the nineteenth century, the military regularly intervened, playing a significant role in politics. Democratic periods were periodically replaced by authoritarian rule.

Moreover, the foreign powers of Great Britain, France, and Russia had factions that influenced the policy of the new state. Indeed, these three foreign powers were tasked with choosing a suitable foreign monarch as King of Greece. The absolutist tendencies of Otto I led to his removal and replacement in 1862 by King George I of the Danish Glücksburg dynasty, which headed the country between 1864 and 1913. Despite this monarchical stability, the democratization process was somewhat discontinuous. Between 1875 and 1922, a two-party system emerged in Greece, dominated by the charismatic leaders Kharislaos Trikoupis and later Eleftherios Venizelos. Notably, the latter shaped most of the first half of the twentieth century by rallying his supporters for a liberal Greece. Between 1910 and 1933, he became prime minister several times but was forced into exile in 1935, when an attempted coup by his supporters against the opposing People's Party government failed (Clogg, 1994: 77-91, 108-117).

During the interwar era, Greece oscillated between dictatorship and democracy. The two most significant periods of dictatorship were those of General 
Theodoros Pangalos (1922-1926), who abolished the monarchy and replaced it with a republic, and the Fascistic dictatorship of General Ioannis Metaxas (1936-1941), which was modelled after the Nazi regime but without its racist genocidal implications. General Metaxas called his state the 'Third Hellenic Civilization', emulating the Nazi 'Third Reich' (Clogg, 1994: 138-140). Following the Nazi occupation (1941-1945), a fierce civil war between the Communist left and the conservative right broke out; a struggle that was to shape the anti-Communist right-wing democracy of the 1950s and 1960s.

The Constitution of 1954 consolidated a majoritarian democracy. Between 1952 and 1967, left-wing groups were banned from the political system. Apart from the internal conflict between left and right in Greece, one must also take the Cold War into account, as Greece was allied with the United States and became a member of the North Atlantic Treaty Organisation. The advent of a moderate left-wing party under Georgios Papandreou that held power in 1963-1965, and the possibility of his return two years later, led to the establishment in 1967 of a military dictatorship that lasted until 1974.

Italy was also compelled to engage in a unification movement to build a nation and state. This process took place during the second half of the nineteenth century, particularly in the 1860s. The unification of Italy in 1870 allowed the establishment of nationhood, which was followed by policies of national integration. Despite such policies, the strong cleavage between the prosperous, assertive north and the impoverished, underdeveloped south was a significant impediment to an economically balanced market. One major party, the Liberals, dominated early Italian politics. It soon split into a more right-wing conservative group and a more left-wing liberal group; however, by the $1880 \mathrm{~s}$, the right and the left had become indistinguishable, such that prime ministers from one faction would include ministers as representatives of the other.

In the nineteenth century, Italian politics was largely controlled by two politicians, Agostino Depretis and Francesco Crispi. These leaders fostered the establishment of a system based on a national network of clientelism and patronage, in which local notables would facilitate the manipulating of elections for the political party in power. This phenomenon became known as transformismo, in which both left-wing and right-wing politicians were motivated not by ideology but by a materialist spoils system. This kind of politics was possible because the electorate was quite small and easily manipulated (Di Scala, 1995: 132).

However, the extension of suffrage, in particular the introduction of universal male suffrage, made it more difficult for the political parties to manipulate elections. Industrialization had led to the growth of an organized working class and subsequently the rise of a Socialist party. Transformismo thus had to be extended to the urban centres. Until World War I, Prime Minister 
Giovanni Giolitti dominated politics, building a more sophisticated variant of the previous network of clientelism and patronage, which became known as Giolittismo. This was a means of incorporating the new industrial masses into the political system. The spoils system of the late nineteenth century, focusing mainly on local notables, was now expanded to encompass the representatives of the working class in the urban centres.

After World War I, Giolitti attempt to continue the practice of Giolittismo, but to no avail. The old system of loose party structures relying on local and urban notables was gone. In its place, the modern political party emerged, as represented by the Socialist Party, the Fascists, and the People's Party (PPI), which was inspired by Catholic social teachings. The rise of Fascist Italy after 1922 put an end to the country's nascent democracy.

After World War II, the new democratic order agreed upon in the Constitution of 1948 was fairly right-wing, similar to that of Greece. The Cold War dictated a strong anti-Communist series of Italian governments that were always dominated by the Christian Democracy party (Democrazia Cristiana DC). The main aim was to prevent the Communist Party from gaining power (Leonardi, 1991: 74-78). Between 1948 and 1993, Christian Democracy was represented in all Italian governments; however, its share of the vote declined considerably in the 1980s and early 1990s. DC formed coalitions with other smaller parties: the Republicans (PRI), Liberals (PLI), and Social Democrats (PSDI), and later the Socialists (PSI) as well. Giuseppe di Palma referred to this party system as one of 'political syncretism', through which DC sought to absorb the smaller parties to perpetuate a dominant political centre (Di Palma, 1978).

In 1992, activist judges under the leadership of Antonio di Pietro uncovered a major national network of systemic corruption associated mainly with DC, but also with PSI (see Guzzini, 1994; Nelken, 1996; Rhodes, M., 1997). Overnight, political parties collapsed and new ones emerged. Although no changes were made to the Constitution of 1948, the post-1993 period is commonly referred to as the Second Republic (see Ceccanti and Vassallo, 2004; Almagisti et al., 2014). Since then, new political parties and actors have evolved; however, the democratic quality has not substantially improved. In particular, Prime Minister Silvio Berlusconi and his business (or personal) party Forza Italia dramatically influenced the Second Republic - some would argue, not for the better (on the concept of the business party, see Hopkin and Paolucci, 1999: 320-332; Paolucci, 2006; Seisselberg, 1996). The deteriorating political discourse in Italy has led to the rise of populist parties that managed to form a government after the 2018 elections. The right-wing populist and anti-immigrant Lega ('League') under the charismatic Matteo Salvini and the citizens' Five Star Movement (Movimento Cinque Stelle - M5S) headed by Luigi di Maio are now shaping the national discourse, to the detriment of 
a more consensual and temperate mode of Italian politics. In September 2019, a more moderate coalition government consisting of PD and M5S came to power, abruptly ending the populist experiment.

\section{The Semi-Peripheral Economies and Societies of Southern Europe}

We are currently witnessing a significant restructuring of the global political economy. This process has been occurring at some level since the fifteenth century: it is a 'Great Transformation' similar to that of the nineteenth and twentieth centuries that emerged from the Industrial Revolution and the establishment of a worldwide British-inspired free-trade regime based on political and economic liberalism (see Polanyi, [1944] 1957). In that era, liberal market economies and liberal democracy became the model of the day. Indeed, as Macpherson (1964) rightly contends, this was a democracy based on possessive individualism, something that remains a permanent feature of capitalism. Whereas the Great Transformation of the nineteenth century focused on creating nation-state-based modernity, reaching its peak as a Fordist society, the present transformation is leading to a global modernity that encompasses the entire planet. We in the information age are living in a period of considerable change based on new technologies related to the internet (see Figure 1.1; Beck, 2008; Castells, 2010; Giddens and Sutton, 2017).

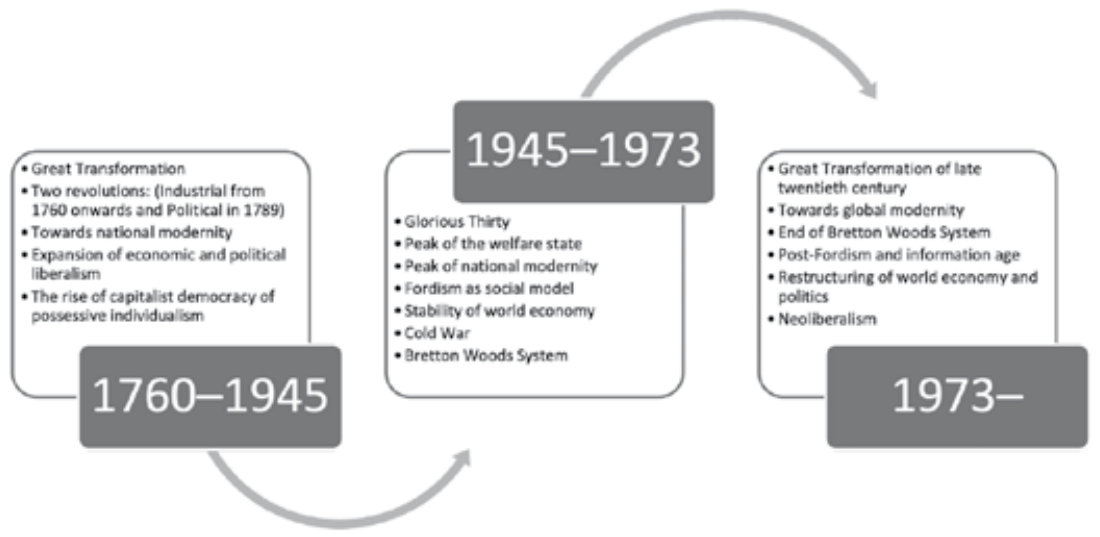

Figure 1.1 The Great Transformation since the nineteenth century

In this book, we use Immanuel Wallerstein's concept of the modern world system as a heuristic device to understand the nature of the national political 
economies of southern Europe. There is uneven development in the global capitalist economy, and there are different levels of integration. According to Wallerstein, we can differentiate between the core, the semi-periphery, and the periphery of the world system (Wallerstein, [1974] 2011: 349). These are not static categories; based on their choices, countries may move from one category to another. As discussed above, countries act as 'competition states' in world markets (Cerny, 1990), meaning that they must have dynamic political economies to provide the social goods (such as education, health, and redistribution policies) necessary to remain competitive in the world market. Consequently, the state plays a significant role in shaping the geopolitical and geo-economic position of a country in the world system. How this role will play out depends on the 'autonomy' of a wide variety of special interests and social groups. The major difference between core, semi-peripheral, and peripheral countries is the state's level of strength in terms of promoting its goals within national and external arenas. In semi-peripheral countries, the state is considerably constrained in its objectives in comparison to the core countries (Wallerstein, [1974] 2011: 336; see also Mouzelis, 1986).

The countries of southern Europe have been characterized as semi-peripheral. This implies that they are intermediate countries between the more highly developed core capitalist economies and the periphery. In his edited volume Semiperipheral Development: The Politics of Southern Europe, Giovanni Arrighi (1985a) was one of the first to compare all four countries as part of this southern European cluster, although he also includes Turkey. As the various authors in the volume show, there are different interpretations regarding how the semi-peripherality of southern Europe can be defined and measured. Despite many commonalities, it is essential to differentiate at least three distinct patterns: namely, those of the Iberian countries, Italy (which is closer to the core countries), and Greece (as part of the Balkan pattern of development; see Ránki, 1985).

In the same volume, Wallerstein comments on the role of the state and the constellation of forces influencing the semi-periphery; at times, semi-peripheral nations are dominated by the core countries, but there are attempts to obtain greater autarky and autonomy. Historically, Wallerstein differentiates between three periods: the period between 1815 and 1914, the subsequent period of Fascism, and the period after World War II in which the Anglo-Saxon global model prevailed. These countries had to re-create themselves after their authoritarian periods. Southern Europe was never a leading region in terms of innovation during the Industrial Revolution, instead serving as a market for the core countries. The existing political systems were moulded according to the British model, but the many distortions permitted the manipulation of elections; as a result, alternation in power was somewhat illusory. By 1914, southern Europe was lagging considerably behind (Wallerstein, 1985: 37). In 
the context of imperialism, Italy was regarded as Italietta ('little Italy'), unable to match the core countries in terms of resources. Enrico Corradini's concept of 'proletarian imperialism' based on the colonization of Africa by the surplus population represented an alternative to the resourceful imperialism of the core countries (Pagano, 2004). The ailing empires of Spain and Portugal were persistently humiliated during the nineteenth and early twentieth centuries: There was the loss of many colonies in the Spanish-American War of 1898, and in 1890, Portugal was forced to accede to the British ultimatum, preventing the country from creating a corridor between Angola and Mozambique (Carr, 1998: 365-373; Oliveira Marques, 1981: 206-209).

As Polanyi diagnosed, in the Great Transformation, Fascism was a response to the Anglo-Saxon conception of a liberal market economy. In all four countries, Fascism played a significant role in creating a large state sector that was strategically utilized to achieve greater autonomy. However, by the end of World War II, the Fascist autarkic model had lost its attraction. Although Spain and Portugal still featured authoritarian dictatorships from 1945 to the 1970s, they ultimately had to make significant adjustments to remain globally competitive. This involved a switch from autarkic policies to the dominant Anglo-Saxon global model, a re-orientation that occurred mainly in the 1960s, with the aperturismo (economic opening) of the Opus Dei technocratic elites in Spain and Salazar's five-year plans. Giovanni Arrighi characterized this as 'market Fascism' (a term coined by the economist Paul A. Samuelson, 1980/1986: 993-994; see also Murteira, 1984). Under US hegemony, the Fascist model abandoned autarkic policies and became hybridized through a controlled opening of the market economy. Greece and Italy were firmly in the orbit of Anglo-Saxon capitalism through their anti-Communist right-wing democracies. Greece experienced seven years of this 'market Fascism' during the Regime of the Colonels dictatorship (1967-1973). According to Arrighi, the adoption of market mechanisms by the authoritarian regimes implied the intrinsic demise of Fascism, as they revolutionized not only the economic but also the social structures. Moreover, such authoritarian regimes became an anachronism in a global hegemonic model based on liberal democracy and a western Europe populated by democracies (Arrighi, 1985b: 269). Market Fascism was an essential factor leading to the transition to democracy in Portugal, Spain, and Greece in the 1970s. Democratic transitions are the result of a prolonged struggle between political elites and social classes. Furthermore, there is an international dimension of this struggle, due to the support of actors from other countries advocating one model over another. The Portuguese Revolution of Carnations is the best example of such processes (the transition period is not discussed here, but this perspective of elite struggle has been put forward by Rustow, 1970: 352-354; on the democratic transitions in southern Europe, see Magone, 1996 and Pridham, 1984; for a Marxist perspec- 
tive on the southern European democratic transitions, see Chilcote et al., 1990 and the classic Poulantzas, 1976).

The European integration process must be regarded as a consensual choice by southern European elites to give up autarkic policies and fully integrate into the supply chains of the core European countries. This integration process led to the illusion that they had become part of the core, despite their weaker economic systems. Before the financial crisis, there was overwhelming support for European integration on the part of national political elites in Portugal, Spain, Greece, and Italy (Conti et al., 2010; Jerez-Mir et al., 2015). The financial and sovereign debt crisis was a wake-up call, reminding the political and economic elites as well as the populations that their semi-peripherality remained a stark reality. In general terms, joining the EC/EU was not the crucial problem for southern Europe, as national sovereignty still prevailed at that time. Everything changed when southern Europe, as a matter of prestige, joined the Economic and Monetary Union in the first wave of members (1999-2001). Since then, these economies have stagnated, as EMU acts as a kind of straitjacket for their choices in economic policy (see Gambarotto and Solari, 2014; Rangone and Solari, 2012). We will return to this later in the chapter in the section on Europeanization and throughout the book.

Wallerstein introduced the concept of 'semi-periphery' and described its changing nature in the context of the continuing restructuring of the world economy, but he did not delve into the semi-peripheral nature of society and politics. Thus far, such work has been conducted primarily by the sociologist Boaventura Sousa Santos and his team at the Institute of Social Studies at the University of Coimbra. His research, ongoing since the 1980s, has focused on the semi-peripheral nature of society, economy, and the state in Portugal; however, his theoretical insights on Portugal are readily transferable to all four countries. Santos's central thesis is that there is a strong imbalance between the productive economic sector based on innovation and competitiveness and the social reproduction system based mainly on consumption patterns (Santos, 1990, 2011). The former undoubtedly features areas of innovation and high productivity, but it is dominated by an entirely unproductive economic structure based primarily on labour-intensive micro-enterprises. The most productive enterprises are foreign rather than domestic. It is straightforward to identify this pattern by referring to the European Union's innovation index. The Innovation Scoreboard includes a considerable number of variables, such as research and development spending in the private and public sectors, patents, number of doctorates, and innovation. It differentiates between innovation leaders, strong innovators, moderate innovators, and modest innovators. Taking the EU28 average in 2010 as 100, Sweden with a score of 148 was the top innovation leader in 2018, followed by Denmark (140), the Netherlands (136), Finland (133), the United Kingdom (128), and Luxembourg (128). 
The group of strong innovators, also encompassed in the core, comprises Germany (127), which is normally in the top group, Belgium (124), Ireland (123), Austria (121), France (116), and Slovenia (98). All of these countries have increased or maintained their innovation level in comparison to 2010. In contrast, the four southern European countries are all moderate innovators, relatively far removed from the top group. The leader of the southern Europeans is Portugal (85), followed closely by Spain (84), Italy (78), and Greece (69); all have been stagnating or decreasing in terms of innovation (European Union, 2018). The second important indicator is the level of productivity per hour. In 2018, productivity per hour in Euros for Luxembourg was $€ 59$, followed by Denmark (€32.9), Ireland (€29), the Netherlands (€27.4), Sweden (€27), Germany (€26.6), Austria (€24), Finland (€22.6), France $(€ 22.2)$, and the United Kingdom (€19.8). In comparison, the southern European countries are lagging in terms of productivity - they may work longer and harder, but not smarter. The figures for southern Europe are as follows: Italy (€15.1), Spain $(€ 14)$, Portugal (€9.4), and Greece (€7.7). Notably, the Nordic countries work on average just 1561 hours per year, producing more value per hour, whereas the southern Europeans need 1825 hours (Greece was the highest in Europe, at 2035 hours) for a lesser value (based on figures from Pinches, 2018; see also Bradshaw, 2020).

Although the productive sectors still trail behind those of the core countries, the social reproduction and consumption patterns are quite similar. This means that there is a disjointed development between production and consumption, leading to an ever-increasing gap between the two (Santos, 1990: 126-135). Despite considerable social progress, the southern European welfare state remains weak and under considerable pressure (Santos, 1990: 135-142); it has elements of universal provision, but this is accompanied by fragmentation in specific areas such as social security and the pension system (on the nature of southern European welfare, see Ferrera, 1996; Rhodes, M., 1996). It is also characterized by informality. As Santos argues, in times of crisis, the welfare state almost collapses and is replaced by the informal 'welfare society'. The family steps in to fill the gaps, suggesting reliance not only on national but also transnational networks due to migrant communities dispersed across Europe and elsewhere (Santos, 2011: 73). Moreover, southern Europe has the highest share of the informal economy in the EU. According to figures calculated by Leandro Medina and Friedrich Schneider, between 2003 and 2015, the informal sector in Greece represented 27.06 percent of the country's Gross Domestic Product (GDP), in Italy 24.95 percent, in Spain 24.52 percent, and in Portugal 21.88 percent. In comparison, the figures for the Nordic countries are as follows: Sweden 13.28 percent, Finland 13.49 percent, and Denmark 15.19 percent (Medina and Schneider, 2018: 69-75). 
As a consequence, we can categorize the southern European countries as semi-peripheral democracies. These are rather 'thin', low-intensity procedural democracies in which civil societies are fairly weak and unable to challenge the state; this contrasts drastically with the strong, high-intensity substantive democracies of the core European countries. In fact, civil society organizations in southern Europe are wholly dependent on subsidies from the state. Social capital is low in southern Europe: according to Robert Putnam, based on a definition set out by James S. Coleman (1988), social capital 'refers to features of social organization, such as trust, norms, and networks, that can improve the efficiency of society by facilitating coordinated actions'. Over time, such social capital becomes sustainable and reified as taken-for-granted reality (Coleman, 1988, 1990; Putnam et al., 1994: 169). During the financial and sovereign debt crisis, there was a considerable increase in social and political contestation, but in reality, such actions were performed by a minority, and they did not have a lasting effect or bring about a sustainable improvement in social capital.

Southern European societies are still characterized by substantial levels of individualism based on amoral familism, implying the importance of loyalty to the family and the widespread avoidance of citizenship responsibility (Auernheimer, 2001; Banfield, 1958; Catanzaro, 2018; Liagouras, 2019). This is reinforced by low levels of interpersonal trust, particularly in Portugal and Greece, and to a lesser extent in Spain and Italy. All this affects the nature of democracy in southern Europe, very much related to the semi-peripheral position of these countries. We will discuss this in later chapters.

\section{THE EUROPEANIZATION OF SOUTHERN EUROPE: THE EU AS A VINCOLO ESTERNO}

In recent years, the theoretical literature on Europeanization has increased considerably in volume. Our main task in this section is to develop an analytical framework of the European integration process since all four countries became members. In effect, the 'Europeanization literature' was irrelevant prior to 1985 because the member-states dominated the European Community. All four southern European countries had joined the EC by then - Italy in 1952-57, Greece in 1981, and the two Iberian countries, Portugal and Spain, in 1986. This timing is quite important, as Europeanization efforts were much less intense at the time.

James Caporaso differentiates between three worlds of integration theory, which may be interpreted as a longitudinal process. First of all, the European Community originally reflected classic theory, concerned with integrating individual parts into a whole; this was the phase that lasted until the late 1960s. The second world is one of polity building and sustaining, a particular focus 
in the 1970 s and early 1980 s. Subsequently, there was a shift from the supranational level back to the member-states. Caporaso refers to this third world as Europeanization (Caporaso, 2008: 33). In this context of the three worlds of integration theory, membership for southern Europe (except for Italy) took place during the period in which the Euro-polity was being relaunched, in the early 1980s. Portugal and Spain became members shortly before the third phase of European integration, which would lead to accelerated Europeanization.

But what does 'Europeanization' mean, and why is it important to differentiate the three worlds of integration theory? Since the seminal article by Robert Ladrech (1994) on the Europeanization of France after the Maastricht Treaty of 1993, there has been a quarter of a century of research on the subject. During this period, despite many attempted refinements, Ladrech's original definition of Europeanization still holds; it was only slightly improved by Claudio Radaelli in another important work in 2003. For our purposes, we use the meaning proposed by Claudio Radaelli due to its more comprehensive character. He defines Europeanization as follows:

Processes of (a) construction, (b) diffusion, and (c) institutionalization of formal and informal rules, procedures, policy paradigms, styles, 'ways of doing things,' and shared beliefs and norms which are first defined and consolidated in the making of EU public policy and politics and then incorporated in the logic of domestic discourse, identities, political structures, and public policies. (Radaelli, 2003: 30)

As Ladrech emphasizes, Europeanization is largely a top-down process of policies agreed at the European level - mainly by consensus in the Council of Ministers and its working groups and in the European Parliament - and then implemented at the national level. In today's internet-infused terminology, it is a 'downloading' process that may be 'hard' (obligatory) or 'soft' (voluntary). 'Hard' compulsory law is generally related to single market or competition policies, the core business of the European Union. This entails regulations and directives decided at the European level. Europeanization in this respect would entail the legal implementation and elimination of differences between countries and then actual compliance in the particular area. 'Soft' or voluntary Europeanization takes place when there are recommendations, best practices, or benchmarking methods of achieving a level playing field across the European Union. Soft governance methods such as the 'open method of coordination' (OMC) or benchmarking are utilized to achieve greater integration in a particular field. Such methods are applied because member-states did not transfer powers in these policies to the supranational level, thus necessitating the adoption of a more long-term and softer approach. In this sense, top-down, vertical Europeanization is not applicable, but rather a more horizontal, transnational process (see Ladrech, 2010: 29-31; on OMC, see De la Porte, 2011). 
Europeanization is not a theory but rather a process within the theories of regional integration. In this regard, it is essential to differentiate between the dimensions, mechanisms, and outcomes of Europeanization. Tanja Börzel and Thomas Risse distinguish between the standard three political dimensions of polity (institutions), politics (interest intermediation, but also the role of political parties as an intermediary between society and state), and policy (e.g., environmental or agricultural policy; Börzel and Risse, 2003: 60). Europeanization directly or indirectly affects various aspects of national politics. In the modern context of a growing cleavage between a more nationally oriented segment of the population and one that is more open-minded concerning globalization and European integration, we may also speak of a political-cultural dimension of Europeanization, as proposed by Christopher Knill and Dirk Lehmkuhl. These authors identify three ways in which Europeanization changes national policy-making: firstly, through negative integration, which for the most part means policies that remove barriers to building the EU's internal market. Secondly, there is positive integration, comprising policies that seek to correct social, territorial, or environmental distortions related to market-building. And thirdly, there is the process of framing integration to modify the beliefs of domestic actors and/or populations (Knill and Lehmkuhl, 1999: 4).

Having clarified the dimensions of analysis, we can attempt to understand the mechanisms of Europeanization. In this regard, Börzel and Risse introduce an exciting approach focused on the 'good fitness' of downloaded policies with national polities, politics, and policies. Good fitness is a crucial aspect, since a good fit will facilitate implementation of intended policies or changes to the polity (here, usually governments and parliaments). Misfit, in contrast, creates tensions, conflicts, and even resistance. The diversity of the political systems among the member-states leads to divergent outcomes of Europeanization. Institutional frameworks, veto players, and political cultures are some of the mediating factors that may affect the success of Europeanization (Börzel and Risse, 2003: 59-69; Ladrech, 2010: 34).

After taking into account the good fit or misfit mechanisms, one can identify the main outcomes of such Europeanization processes. Here, the impact is differential according to the good fit or misfit factors, such that different countries may experience different outcomes. According to Börzel and Risse, these differential outcomes are as follows: inertia, retrenchment (resistance to change), absorption (low degree of change), accommodation (adaptation without changing core or essential features), and transformation (Börzel and Risse, 2003: 71-73; Ladrech, 2010: 36). The southern European countries represent cases of either low or medium change. In particular, Greece has persistently exhibited inertia or retrenchment, whereas Italy, Portugal, and Spain have shown patterns of absorption and accommodation. Several studies seem to confirm that the southern European countries are relative laggards in terms 
of adaptation to the pressures of Europeanization. They have a much lower level of compliance with EU law than the northern countries, particularly in comparison with the United Kingdom, Germany, and Denmark (Börzel et al., 2010: 1382).

This was also confirmed in a study conducted by Falkner et al. (2005) on compliance with social policy directives. Although social policy is a national competence, the EU has been using the internal market to legislate soft framework laws in some areas of employment relations. The best countries in terms of political and administrative compliance with EU legislation are the Nordic countries (world of compliance); the weakest are most southern European countries, namely Italy, Greece, and Portugal (world of neglect). Germany, Austria, and Spain are in between, due to political and administrative blockades in the national multilevel governance system (world of domestic politics; Falkner et al., 2005: 330-340).

In southern Europe, Europeanization has been differential and acts mostly through a mechanism of misfit due to the resisting or persisting structures and vetoing of players at the national level. Southern European countries experienced a kind of superficial Europeanization up until the financial and sovereign debt crisis, resisting changes to the 'way of doing things' (Radaelli, 2003: 30; for more on differential Europeanization, see Héritier, 2001).

Our book intends to develop an understanding of the paradox whereby southern European countries have been among the strongest supporters of European integration but simultaneously among the greatest laggards in terms of compliance with EU law and adjustment of polity, politics, and policy dimensions to the momentum of European integration. Indeed, the southern European political elites and populations seem to follow the logic of the vincolo esterno (external constraint). This logic implies that a new member-state, regarding the EU as a more advanced polity, hopes that through membership the EU will resolve all domestic impediments to socio-economic development and democracy. The approach of the vincolo esterno is passive rather than proactive. The member-state believes that merely via integration, changes will take place over time with almost no input from political elites or the population. The concept was originally developed for Italy by Guido Carli, former president of the then-principal business confederation Confindustria and president of the Italian National Bank: the then-EC was regarded as the vincolo esterno that would shape Italian modernization (Carli, 1993: 5-6, 8). The concept became popularized for all southern European countries following an article written by Kenneth Dyson and Kevin Featherstone on how the Italian prime minister Romano Prodi enabled Italy to join the first wave of EMU countries, despite the fact that the nation had a public debt over 100 percent of its gross domestic product (GDP) at the time, and the budget deficit threshold of 3 percent of GDP was only achieved by introducing a new gasoline tax. This was not a very 
sustainable approach to becoming a member of EMU. Nevertheless, for Italy, it was a matter of prestige to be at the forefront of European integration (see Dyson and Featherstone, 1996; for the Greek case, see Panagiotarea, 2013). The vincolo esterno mentality reached its peak at Greek Prime Minister Alexis Tsipras's U-turn after the 2015 referendum on the third bailout agreement. The political and economic elites of the country did not want to leave the Euro, and Tsipras had to deliver. However, after his bluff was exposed, Tsipras was forced to accept even worse conditions in the bailout agreement (Tsatsanis and Teperoglou, 2016; Varoufakis, 2017).

Our thesis here is that the southern European countries joined the EC during a period in which member-states were the dominant agents. The integration process had been stalling for quite a few decades, and there were no real attempts at true Europeanization. However, Jacques Delors's presidency of the European Commission (1985-1995) changed the rhythm of integration almost overnight. Delors's leadership and voluntaristic approach led to the significant transformation of the EC into the EU. The so-called 'Russian doll approach' resulted in the establishment of a Single European Market (SEM) by 1993, Economic and Monetary Union (EMU) by 1999, and the doubling of the EU budget twice in 1988 and 1992 (on the Russian doll approach, see Ross, 1995). The increase in financial resources was primarily allocated to the EU's cohesion policy, which sought to create equal access to the SEM across the European Union. This rather constructivist programme was to transform the EU considerably; however, it required a significant level of compliance and support from the member-states, as the new legislation focused not only on market-building (negative integration) but also on market-correcting (positive integration) measures. Delors wanted the EC/EU to become a competitive economic superpower in its own right, challenging the United States and Japan (see Cecchini et al., 1988). At the end of Delors's tenure as president of the European Commission, the union's transformation from a member-state-dominated EC to the higher level of supranationalized policy-making had been achieved. New potential member-states from central and eastern Europe faced Caporaso's third phase of regional integration theory (see above), Europeanization - a much stricter process than that experienced by southern Europe. 'Conditionality' and annual screening based on the Copenhagen criteria streamlined the process of central and eastern enlargement that began in 1993, as the criteria clearly defined what was expected from new member-states. The conclusions of the Danish presidency of the EU on membership conditionality states as follows:

Membership requires that the candidate country has achieved stability of institutions guaranteeing democracy, the rule of law, human rights and respect for and protection of minorities, the existence of a functioning market economy as well as 
the capacity to cope with competitive pressure and market forces within the Union. Membership presupposes the candidate's ability to take on the obligations of membership including adherence to the aims of political, economic and monetary union. (European Council, 1993: 13)

It took a decade, until 2004, to achieve central and eastern European enlargement. In contrast to the southern European expansion, the new candidate countries were already engaged in anticipatory and adaptive Europeanization before they even joined the European Union (Agh, 2003). The transformation of these former Communist regimes involved many sacrifices (for a review, see Schimmelfennig and Sedelmeier, 2005). Between the southern enlargement and that of central and eastern Europe, the EC/EU's approach had changed considerably. In the 1980s - still in the second world of regional integration theory - the EU was a relatively benevolent soft actor, allowing integration without profound Europeanization. In the 1990s and in the new millennium, it had become a conditionality-led and intrusive hard actor, combining requirements for integration with a high level of Europeanization.

After 2008, the EU became anxious about the dire economic situation in the Baltic states that had ambitions to join EMU. Moreover, the new members Bulgaria and Romania were badly affected by the crisis. The so-called 'REBLL' (Romania, Estonia, Bulgaria, Latvia, and Lithuania) group implemented harsh austerity policies demanded by the International Monetary Fund (IMF), becoming a 'model' for the new austerity approach of the Brussels and Frankfurt technocracy (Blyth, 2015: 216-225).

When the financial and sovereign debt crisis emerged in the context of EMU, southern Europeans were still hopeful that the EU would react in a benevolent manner. Instead, policies of 'coercive' Europeanization based on 'conditionality' became the norm: the REBLL model had won the day.

\section{SUPERFICIAL EUROPEANIZATION AND SEMI-PERIPHERAL GOVERNANCE}

This differential impact allows us to distinguish between core countries (Germany, Benelux, France, Austria, Finland), capable of successfully responding to Europeanization efforts in order to contribute to a more competitive European economy, and the southern, central, and eastern European periphery, which is struggling to keep up with the pace in an EMU designed for the core. A core-periphery divide is becoming a salient reality of European integration (see Magone et al., 2016).

The European Union's multilevel governance system is a complex cluster of inter-organizational networks. These networks are self-organizing and based on dense interactions between political institutions (governments) that 
are organized as hierarchies, economic actors such as enterprises and rating agencies governed by market competition, and civil society organizations that adjust to both government and markets. In this regard, the post-1985 model of the European Union has been strongly influenced by elements of New Public Management (NPM) in an effort to make policy-making more efficient and increase value for money. This is the Anglo-Saxon model of governance, which became a central aspect of the EU multilevel governance system. This is important because the model emerged at the end of the 1970s, when the UK, the USA, and other countries were stagnating economically, and there was an urgent need to make the state more efficient and competitive. Throughout the 1980s and 1990s, the Thatcherite British experience served as a template for the transformation of the state in Europe. Rod A.W. Rhodes has defined governance as 'self-organizing networks' combining political institutions, economic actors, and civil society organizations (see Rhodes, R. 1997, 2017; for the transformations of the state, see also Cerny, 1990; Leibfried and Zürn, 2005). Such restructuring is still ongoing, and the European Union has become a significant agent in this respect. The result has been the transformation of the rigid Weberian welfare state, which separated public and private, politics and economy, into the competition workfare state.

This model was then implemented across Europe. European integration contributed to the restructuring of national systems of government into a multilevel system of governance based on the de-regulation of the economy at the national level, and re-regulation at the supranational level. Moreover, an extensive programme of privatization of the state enterprise sector and state-owned utilities took place as part of the policies of the European internal market. Non-majoritarian agencies (i.e., non-accountable, non-elected structures) were tasked with de-regulating markets at the national level and re-regulating at the supranational level. As a result, Giandomenico Majone calls the European Union a 'regulatory state', using more of a light touch approach to restructuring the emerging European market. This process was strongly influenced by experiences in the United States (Majone, 1996: chapters 3 and 4).

However, the transfer of the Anglo-Saxon model to southern, central, and eastern Europe produced an entirely different result. One major problem was that in these regions, the state and its institutions, the national market economy, and civil society are all weak. Under such circumstances, the outcomes of governance are not the same as in more developed democracies and economies. Furthermore, these imposed policy networks were built in a socio-cultural environment of low interpersonal trust; high interpersonal trust is a precondition for the new governance model (Rhodes, R., 1997: 57).

Therefore, it makes sense to develop a typology of national governance in the European Union. By using a simplified perspective, we can identify three kinds of governance at the national level. Firstly, there is the ideal type of 
core national governance in which trust, democratic accountability, and transparency are important aspects of self-organizing policy networks involving stable governments (hierarchies), the economy (market), and civil society. Governance leads to the achievement of set goals through a highly dense web of interactions between the three actors. Secondly, there is the type of peripheral national governance found more often in southern, central, and eastern Europe, in which socio-cultural distrust tends to prevail. Here, democratic accountability and transparency are frequently neglected because these policy networks are poorly institutionalized and taken for granted by a resisting hierarchical governmental structure. The state and its institutions, the national market economy, and civil society are all weak, such that these actors mutually undermine successful policy-making outcomes. Instead, pseudo-policy networks are established simply because supranational actors and international institutions such as the Organisation for Economic Cooperation and Development (OECD) have recommended it, without taking into account the conditions in the specific country. This phenomenon becomes evident in the way cohesion policy has been implemented in southern Europe.

The consequence is strong dominance of the political institutions in the networks established for the implementation of cohesion policy. I call this the 'governmentalization' of these weak and not very dense networks. We will return to this issue in Chapter 7. For this introductory chapter, it suffices to lay out a framework of analysis to facilitate an understanding of Europeanization in southern Europe and why it has had a different effect than in more advanced economies. Figure 1.2 shows in a simplified triangle the relationships in governance as self-organizing networks in the more highly developed economies and democracies of the European Union (i.e., the core) and in the less-developed economies and democracies in the (semi-)periphery. In more advanced democracies and economies, the triangle consists of strong institutions, strong economic actors, and strong, well-established civil society actors. In (semi-)peripheral democracies, the triangle involves weak institutions, weak economic actors, and weak civil society actors, in many cases dependent on subsidies by the state. The typology would not be complete if we did not include a worst-case scenario of networks that have completely captured the state. Such a problem also exists in southern Europe. Until 1992, Italy was plagued by a web of systemic corruption centred around the main party, Christian Democracy, as well as by the challenges posed by the various Mafias across the territory. Oligarchs, a feature that can be found in most Balkan countries, are also quite dominant in Greece. This state-capture model of misgovernance is rampant in the Balkan countries and in the post-Soviet states (on state capture, see Heinrich Böll Stiftung, 2017; Tudoroiu, 2015).

Our focus will be on a study of the member-states characterized by (semi-) peripheral governance, primarily southern Europe. The typology simply serves 


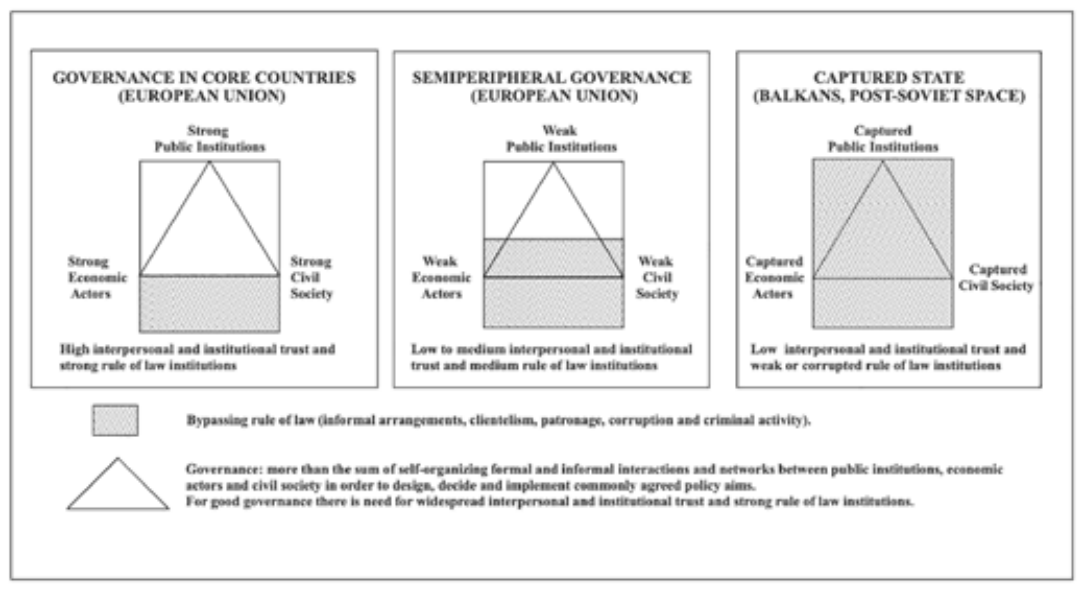

Figure 1.2 Types of core, periphery, and state capture governance

as guidance to understand the differences between core and peripheral governance, as well as those between the individual southern European countries. We assume, for example, that Spain and Italy have greater autonomy, despite their overall peripheral structures, than Portugal and Greece (see Table 1.1).

\section{CONCLUSIONS: THE PERIPHERAL GOVERNANCE OF SOUTHERN EUROPE IN THE EUROPEAN UNION}

In this chapter, we have delineated the main features of southern European politics and economies, illustrating the major differences between the core and peripheral countries of the European Union.

We have developed a heuristic typology of governance, taking into account the differential impact of Europeanization in various European countries, mainly southern Europe. The three types involved are core, peripheral, and state-capture governance; southern Europe belongs to the peripheral governance group. We intend to investigate the issues involved with this peripheral governance and how attempts at Europeanization have influenced and framed its development. 
Table 1.1 Advanced and peripheral governance

\begin{tabular}{|c|c|c|c|}
\hline & Advanced Governance & Peripheral Governance & State Capture \\
\hline Economy & $\begin{array}{l}\text { Social Market } \\
\text { Economy: Sustainable } \\
\text { national economy with } \\
\text { strong research and } \\
\text { development enterprises, } \\
\text { integrated economy }\end{array}$ & $\begin{array}{l}\text { Semi-peripheral Market } \\
\text { Economy: Unsustainable } \\
\text { national economy } \\
\text { with predominantly } \\
\text { micro-enterprises without } \\
\text { innovation potential, strong } \\
\text { dependency on foreign capital, } \\
\text { dual economy, large informal } \\
\text { sector in the economy }\end{array}$ & $\begin{array}{l}\text { Oligarchised Market } \\
\text { Economy: Dominance } \\
\text { of informal economic } \\
\text { networks around oligarchic } \\
\text { figures, with colonization } \\
\text { and control of core state } \\
\text { sectors for corrupt and } \\
\text { criminal exchanges }\end{array}$ \\
\hline $\begin{array}{l}\text { Labour Market, } \\
\text { Welfare State } \\
\text { Relations }\end{array}$ & $\begin{array}{l}\text { Balanced Flexicurity } \\
\text { (emphasis on the } \\
\text { flexibility of labour } \\
\text { markets, but backed } \\
\text { up by robust security } \\
\text { systems) }\end{array}$ & $\begin{array}{l}\text { Imbalanced Flexicurity } \\
\text { (emphasis on the flexibility of } \\
\text { labour markets, but security } \\
\text { systems are inadequate) }\end{array}$ & $\begin{array}{l}\text { The informal sector is quite } \\
\text { large, and the labour market } \\
\text { poorly monitored. } \\
\text { Welfare state used } \\
\text { for clientelistic and } \\
\text { patronage-based } \\
\text { constituency building }\end{array}$ \\
\hline $\begin{array}{l}\text { Industrial } \\
\text { Relations }\end{array}$ & $\begin{array}{l}\text { Industrial relations } \\
\text { system still plays } \\
\text { a role in terms of } \\
\text { light regulatory } \\
\text { neocorporatism }\end{array}$ & $\begin{array}{l}\text { Industrial relations } \\
\text { system biased towards } \\
\text { business associations to } \\
\text { regain competitiveness; } \\
\text { precariousness of labour } \\
\text { conditions }\end{array}$ & $\begin{array}{l}\text { Poor industrial relations, } \\
\text { lack of workers' rights and } \\
\text { high levels of precarious } \\
\text { labour conditions }\end{array}$ \\
\hline State & $\begin{array}{l}\text { Strong steering capacity } \\
\text { of the state, primus inter } \\
\text { pares }\end{array}$ & $\begin{array}{l}\text { Weak steering capacity of } \\
\text { the state; however, it is the } \\
\text { dominant player, as the } \\
\text { capital-poor, weak civil } \\
\text { society, the private economic } \\
\text { sector, and other actors are } \\
\text { dependent on subsidies from } \\
\text { the state }\end{array}$ & $\begin{array}{l}\text { State captured by oligarchic } \\
\text { groups and criminal groups } \\
\text { linked to politicians and } \\
\text { political parties. Lack of } \\
\text { independence of the state } \\
\text { from these oligarchic and } \\
\text { criminal interests }\end{array}$ \\
\hline Civil Society & $\begin{array}{l}\text { Strong, sustainable civil } \\
\text { society }\end{array}$ & $\begin{array}{l}\text { Weak, unsustainable civil } \\
\text { society (highly dependent on } \\
\text { subsidies from the state) }\end{array}$ & $\begin{array}{l}\text { Weak civil society, strongly } \\
\text { manipulated by external } \\
\text { and internal actors }\end{array}$ \\
\hline
\end{tabular}

